\title{
Community based waste management and its utilization for sustainable
} environment

\author{
SK Sarkar* ${ }^{1}$, MK Uddin ${ }^{2}$ \\ ${ }^{1}$ Rural Development Academy (RDA), Bogra; ${ }^{2}$ Department of Environmental Sciences, Jahangirnagar \\ University, Dhaka, Bangladesh
}

\begin{abstract}
The goal of this study of community based waste management and utilization was to reduce the major negative impact of environment and health hazards created by improperly managed waste mainly focusing on livestock production system of Bangladesh. The waste amounted 4,78,220 kg annually managed by the community contribute to significant role regarding human and livestock health, sanitation, economic as well as environmental aspects. In terms of economic, the Chadkarim community could earn net benefit of Tk. 2,70,146 in 2012 by selling waste by-products, major earnings come from 95,644 kg of organic fertilizer producing amounting Tk. 1,37,546 The global environmental perspective is to reduce livestock-induced, land-based pollution and environmental degradation. One of the major costs of running an agricultural farm can include buying nitrogen in the form of anhydrous ammonia to fertilize crops. But there are other agricultural costs associated with nitrogen, especially when the nitrogen in livestock waste produces pungent and potentially harmful ammonia emissions. To get expected production and to trap optimum socio-economic benefit from livestock rearing, waste must be managed in proper ways through a community based biogas producing approach of waste management to have sustainable environment. During one year community managed 4,78,220 kg degradable waste and produced about $17,216 \mathrm{~m}^{3}$ of biogas and utilized that gas for cooking and electricity generation. The notable benefits come from women's saved time and money. The 200 households at the community in one year have saved 15,881 working days through reduced time required for managing of fuel and cooking purposes. Most of the saved time is being utilized for household tasks and for education of the children. This is one of the greatest contribution to the nation.
\end{abstract}

Key words: Community, waste management, sustainable environment

Bangladesh Animal Husbandry Association. All rights reserved. Bang. J. Anim. Sci. 2013. 42 (2): 165-173

\section{I ntroduction}

In decades past, livestock waste management was not considered to be much of a problem. However, as milk and meat production need increased, herd size and waste production also increased. This has finely tuned the awareness for waste management. Any livestock operation, regardless of size, that is causing a pollution problem must need to follow the regulations.

Regarding waste management more than a decade ago, Rural Development Academy (RDA), Bogra conceived and implemented the waste management program in RDA campus, especial emphasis was given on demonstration farm with the aim of putting the brakes on environmental pollution caused by livestock waste. RDA through action research project worked for five years to address these issues and will discus potential of replication to the other regions of Bangladesh.
Livestock is a significant global asset with a value of at least $\$ 1.4$ trillion (Steinfeld et al. 2006). The livestock sector is increasingly organized in long market chains that employ at least 1.3 billion people globally and directly support the livelihoods of 600 million poor smallholder farmers in the developing world (Thornton et al. 2006). Keeping livestock is an important risk reduction strategy for vulnerable communities, and livestock are important providers of nutrients and toehold for growing crops in smallholder systems. Livestock products contribute 17 per cent to kilocalorie consumption and 33 per cent to protein consumption globally, although there are large differences between rich and poor countries (Rosegrant et al. 2009).

Livestock systems have both positive and negative effects on the natural resource base, public health, social equity and economic growth (World Bank 2009). Currently, livestock is one of 


\section{Community waste management}

the fastest growing agricultural subsectors in developing countries. Its share of agricultural GDP is already 33 per cent and is quickly increasing. This growth is driven by the rapidly increasing demand for livestock products, this demand being driven by population growth, urbanization and increasing incomes in developing countries (Delgado 2005).

The global livestock sector is characterized by a dichotomy between developing and developed countries. Total meat production in the developing world tripled between 1980 and 2002, from 45 to 134 million tons (World Bank 2009). Much of this growth was concentrated in countries that experienced rapid economic growth, particularly in East Asia. In developed countries, on the other hand, production and consumption of livestock products are now growing only slowly or stagnating, although at high levels. Even so, livestock production and merchandizing in industrialized countries account for 53 per cent of agricultural GDP (World Bank 2009). This combination of growing demand in the developing world and stagnant demand in developed countries represents a major opportunity for livestock keepers in developing countries, where most demand is met by local production, and this is likely to continue well into the foreseeable future. At the same time, the expansion of agricultural production needs to take place in a way that allows the less well-off to benefit from increased demand and that moderates its impact on the environment.

Though, first use of biogas in the country started in 1972 at Bangladesh Agricultural University (BAU) campus, but really since 1990s the expansion of biogas as a source of fuel has got some momentum. The Infrastructure Development Company Limited (IDCOL) that emerged Bangladesh in 2006 has by now become one of the major agencies expanding biogas plants at the family level across the country. The family based approach for managing livestock waste (mainly dung) found to be less contributory and time consuming with higher cost involvement implemented by other GOs \& NGOs in Bangladesh. Some 37,269 domestic biogas plants targeted to be installed by 2012 (Survey report2010) across the country with the support of Netherlands Development Organization (SNV) through the partner organizations of IDCOL under the National Domestic Biogas and Manure Program (NDBMP). Considering the trends and situation of waste management initiatives particularly for rural areas the researcher felt to find out suitable and affordable alternatives of producing renewable energy, bio-fertilizer, sustainable livelihoods and friendly environment through biogas plant led by community based waste management approach in Bangladesh.

This paper attempts to provide present status of livestock waste management systems in relation to recent trends, coupled with a brief assessment of whether these trends are likely to continue into the future. Also indicates where potential remains, in relation to livestock waste management and livestock disease control under community initiatives. Study sketches of a number of factors that may modify both the production and the systems of livestock waste management in an efficient manner. The paper concludes with a summary outlook on community based waste management systems and utilization towards sustainable environment. The objective of the study is to assess the feasibility to set-up and implement a community based biogas plant and its potentials for proper livestock waste management in Bangladesh.

\section{Materials and Methods}

The overall methodological approach is focused on integration of quantitative and qualitative methods. Along with questionnaire, which is the main source of data, a number of qualitative tools have been used for data collection. The findings from the questionnaire survey and qualitative investigation are made complementary to each other throughout data collection to analysis phases. The following methodologies were used to address the objective of the study:

- Analyses of secondary data including project documents from Rural Development Academy (RDA), Bogra, Bangladesh.

- Field visits to get an impression on the performance of biogas plant and to collect practical information on community biogas project implemented by RDA in Chandkarim village, Sadullahpur, Gaibandha.

- A check-list was prepared for the collection of data during the field visits. 
- Interviews with key informants and potential stakeholders for community biogas users.

- Determination of key conditions for dissemination of community based biogas plants in Bangladesh.

\section{Study location}

The Rural Development Academy (RDA), Bogra, Bangladesh, runs a poverty alleviation project at Chandkarim village under Gaibandha district in the northwest of Bangladesh. This study was conducted in Chandkarim to identify the feasibility to set-up and implement a community based biogas plant towards proper livestock waste management to changes in the livelihood patterns of people in the community. A participatory approach was used for both qualitative and quantitative data collection between January to March 2013. Participants interviewed were engaged in community biogas plant management and allied income-generating activities such as livestock rearing, beef fattening, poultry rearing, biogas \& electricity sales, organic fertilizer packaging and selling, fish farming, fish marketing and home gardening. Respondents were selected randomly from the study area covering various categories according to the lands ownership.

\section{Sources of waste used}

The community used crop field as the major source of fuel and biomass. The amount of contribution of biomass waste was not same for all farm categories. The biomass in the study area comes from different field crop residues. Most of the villagers use their biomass as fuel from the crop residues (maize straw, bottom part of rice straw, husk, etc.), followed by dried cowdung cake, leaves and twigs, kitchen byproduct, etc.

As there is no availability of natural gas and electricity, most of the respondents depend on natural sources of biomass for cooking. For lack of community forests, the farmers collect fuel wood from the homestead forestry. The main sources of biogas production materials are livestock waste $(91 \%)$, poultry droppings $(5 \%)$, kitchen waste $(3 \%)$ and others $(1 \%)$ etc. (not shown in Table).
Leaves and twigs: The estimation of leaves and twigs were based on gathering by the farmers. By field data amount of gathered leaves and twigs per household per day was recorded and the amount was calculated on year basis, multiplying the amount by the weightage of the leaves and twigs.

Cowdung: The total number of cattle in the community present was recorded before and after project started 255 and 320 respectively. The quantity of cowdung (dry basis) was calculated by multiplying the cowdung production per head per year and the number of cattle in the community. The cowdung (dry basis) quantity per head per year was found 0.51 ton in the study area which was almost similar to the cowdung (dry basis) quantity per head per year was estimated as 0.49 ton for Mymensingh area (Chowdhury et al. 1987).

Goat faeces: The dry biomass obtained from goat faeces per head in the study area was also estimated by the same method used in cattle. The goat faeces quantity per head per year was found $18.94 \mathrm{~kg}$ in the study area which was almost similar to the finding (dry matter basis) per head per year was estimated at $19.25 \mathrm{~kg}$ (Shahjalal et al. 1997).

Poultry droppings: According to Uddin (1991) average per head poultry dropping production was estimated at $10.95 \mathrm{~kg}$ on dry matter basis but in the study area it was $11.24 \mathrm{~kg}$ per bird per year.

Total dry matter (DM) from livestock used as input for the biogas plant was calculated by the following formula:

$$
W c d=\frac{\sum_{i=1}^{n} \operatorname{Pcr}(i) x f c r(i)+G d p(i) x F d p(i)+P d p x F d p}{\sum_{i=1}^{n} C d p+G d p+P d p}
$$

where, Wcd=total cow dung used as input of biogas plant by the community, ton; $\mathrm{Cdp}=$ production of dried cow dung of (i) family, ton; $\mathrm{Gdp}=$ production of dried goat faeces of (i) family, ton; $\mathrm{Pdp}=$ production of dried poultry droppings of (i) family, ton; $F d p(i)=$ percentage of dry dung 


\section{Community waste management}

used as input by (i) family, ton; $n=$ number of family of a community.

\section{Total fuel consumption for cooking}

Total fuel consumption for cooking was calculated by using the following formula:

$$
\text { TFcon }=\sum_{i=1}^{n} W \text { fuel }(i) \times H f u e l(i)
$$

where, $T_{\text {Fcon }}=$ total fuel consumption for cooking, $\mathrm{kg} /$ year; $W_{\text {fuel }}(\mathrm{i})=$ weight of (i) fuel for cooking, $\mathrm{kg} /$ year; $\mathrm{H}_{\text {fuel }}(\mathrm{i})=$ heating value of (i) fuel, $\mathrm{kJ} / \mathrm{kg}$; $n=$ number of fuel type.

\section{Results and Discussion}

Livestock sector can solve the unemployment problem of the rural people and can ensure the sustainable multipurpose use of our land. So this sector has the ability to ensure the certain mobility of the economy of Bangladesh through poverty reduction, nutrition supply and employment generation. To get optimum benefit from livestock, waste produced with proper management through community biogas plant can be one of the potential factors. Community based Biogas Plant: Community based refers to the social unit shares common values. The findings showed per year net earning captured by the Chandkarim village community stood at Tk. 2, 70,146 (Table 3). Though, total efficiency of waste management incurred by the community biogas plant was near about $50 \%$ only.

\section{Experience of RDA on community based waste management}

The plants based on Fixed Dome and community based waste management concept were developed by Rural Development Academy (RDA), Bogra in 2002. The design is based on principle of "Semi Batch-fed Digester". A combination of batch and semi-continuous digestion is known as semi-batch fed Digestion. It also called Fixed Dome Digester. Such a digestion process is used where the dung/droppings from domestic farm animals is sufficient to operate a plant and the same time organic waste like crop residues, agricultural wastes, kitchen waste, weeds etc. are available during the season. But RDA's Fixed Dome CBP (Community Biogas Plant) use cow dung as the major substrates. This plant has an inlet pipe connected to BGP for daily feeding of cow dung directly from animal's shed. The semi-batch fed digester has much longer digestion cycle of much gas production as compared to the batch-fed digester. The batchfed digester is ideally suitable for traditional family base small and medium farmers having 68 cattle's or 20-30 goats to meet the basic cooking requirement and at the end of the cycle it gives enriched organic manure in the form of digested slurry (Mamun et al. 2009; Islam et al. 1999). Actually, RDA developed CBP offers a package system which mainly included e.g. a need based biogas plant (minimum vol. $130 \mathrm{~m}^{3}$ ) for managing waste; biogas generator to generate electricity, deep tube well to have safe water both for community and running biogas digester smoothly, pipeline both for water and biogas supply to the households level and a drying cum processing floor to manage organic fertilizer etc. with to some extent financial support of training match income generation activities (IGAs) towards sustainability.

\section{Homestead energy use}

Homestead energy is used for a particular household was estimated through different daily activities performed by the family. The activities included for using energy were cooking, parboiling of rice, lighting, providing smoke to the cow shed and so on. The average homestead fuel energy requirement was estimated to be 83.86 GJ/Yr per household (Rabbani et al. 2011).

\section{Utilization pattern of biogas}

Utilization pattern of biogas was observed in Chandkarim village from community biogas digester supply of biogas to 17 families, for cooking and 1 cowshed for water boiling. On demand basis this biogas is also used for 5KVA biogas generator for production of electricity which was connected to 43 households for lighting (Table 6). 
Table 1. Comparative statement of "Chandkarim" community and traditional biogas plant

\begin{tabular}{ll}
\hline Traditional Biogas Plant & Community Biogas Plant \\
\hline Family based & Community based \\
\hline Small unit (1.2-4.8 $\mathrm{m}^{3}$ ) & Bigger in size $\left(83-200 \mathrm{~m}^{3}\right)$ \\
\hline Waste management in household level & Active participation in waste management \\
\hline Individual family use & Common output sharing \\
\hline Individual contribution with subsidy & Community investment without subsidy \\
\hline Only Bio-gas plant & Package support for sustainability \\
\hline Cost Tk. 0.35-0.60 Lakh & Total investment Tk. 14.5 Lakh \\
\hline One family only & Family coverage: $120-200$ families \\
\hline Waste management capacity- 30-60 kg./d & Waste management capacity- 2-2.5Ton/d \\
\hline Improper decomposition & Proper decomposition \\
\hline Daily gas output- 1.1-2 $\mathrm{m}^{3}$ & Daily gas output- 50-90 $\mathrm{m}^{3}$ \\
\hline Manure output- 6-12 kg/day & Manure output- 400-500 kg/day \\
\hline No water supply system & Safe water supply system \\
\hline No generator & Biogas generator for electricity (5KVA) \\
\hline Only biogas line connected to individual family & Main grid pipeline for supply of water and biogas \\
\hline High cost & to the community households \\
\hline Least scope of benefit sharing & Average cost minimal \\
\hline
\end{tabular}

Table 2. Seasonal variation of dung based Plants

\begin{tabular}{|c|c|c|c|c|c|c|c|c|c|c|c|c|}
\hline \multirow[t]{2}{*}{ Item } & \multicolumn{12}{|c|}{ Month (January - December) } \\
\hline & 1 & 2 & 3 & 4 & 5 & 6 & 7 & 8 & 9 & 10 & 11 & 12 \\
\hline Availability of raw materials & $\sim$ & $\sim$ & $\widehat{\mho}$ & & & $\widehat{U}$ & & 几 & $几$ & 几 & $几$ & \\
\hline Gas availability & z & 几 & $\widehat{U}$ & 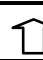 & & $\sim$ & $\square$ & $\square$ & & $\sim$ & $\sim$ & $\square$ \\
\hline Quantity of slurry produced & 几 & & & $\widehat{T}$ & $几$ & 口 & & & & & & $\square$ \\
\hline
\end{tabular}

, Normal; 凹, More than normal; 凤, Less than normal

\section{Economic analysis of community biogas plant at chandkarim village}

The total gas production of Chandkarim bio-gas plant per day was estimated to be $60-90 \mathrm{~m}^{3}$ at 210 millibar pressure. The estimated expenditure of CBP was Taka 762674 per year. The gross return from this biogas plant was estimated at Taka 1032820 per year of which net return from biogas was Taka 54,600 and from bio-fertilizer ranked highest (Taka 1,37,546). Biogas plant produces slurry as byproduct produces biofertilizer. The return from bio-fertilizer was found much higher than the return from bio-gas. The overall benefit-cost ratio of the bio-gas plant was found 2.82, which was very promising (Table $3)$. According to villager's opinion, the cost of supply of bio-gas per family per month at
Chandkarim was estimated as Taka 1506.85, whereas, the cost of supply of LP gas per family per month was Tk. 1723.35. Therefore, the user of Chandkarim village is benefited by Taka 216.50 per family per month by supplying biogas to its households. However, the Chandkarim community is subsidizing Taka 1106.85 per family per month by collecting Taka 400 from each household per month and allowing each household a benefit of Taka 1323.35 per month (Table 4). This finding is almost similar to Mamun et al. (2009).

\section{Cowdung as input for biogas production}

Traditionally, cowdung, which in the forms of dried cowdung cakes and cowdung with sticks, is used to cook food, which rather could be used as 


\section{Community waste management}

feed source of biogas digester turn into biogas as renewable energy and organic manure for soil organic matter enrichment, enhanced water holding capacity and which ultimate would lower the need for chemical fertilizer and of course environment friendly.

A number of barriers hold back a small scale biogas plants as commercial entrepreneurship due to lack of active participation for collection and providing waste as feed materials to the biogas plants to make its efficiently use. It is difficult to make biogas plants cost-effective with sale of energy as the only source of income. That is why; planners and decision-makers have to come forward instead of establishing small sized traditional family based biogas technology which is not feasible and cost-effective. Study reveals that about $60 \%$ are inactive. Average price per $\mathrm{kg}$ of raw materials supplied as input to the biogas plant by waste category at chandkarim village, sadullahpur, Gaibandha was Taka 0.50 for cowdung; 0.55 for poultry droppings; 0.90 for kitchen waste \& 0.50 for others respectively including sorting and carrying cost (Table 4).

Table 3. Daily average amount $(\mathrm{kg})$ of raw materials supplied to the Biogas Plant by waste category

\begin{tabular}{lccccc}
\hline \multirow{2}{*}{ Month } & \multicolumn{5}{c}{ Average amount $(\mathrm{kg})$ of raw materials used /day } \\
\cline { 2 - 6 } & Cowdung & Poultry droppings & Kitchen waste & Others & Total \\
\hline January & 1080 & 30 & 41 & 13 & 1164 \\
February & 1337 & 30 & 48 & 14 & 1429 \\
March & 1521 & 32 & 46 & 11 & 1610 \\
April & 2438 & 42 & 60 & 32 & 2572 \\
May & 1315 & 39 & 39 & 20 & 1413 \\
June & 928 & 47 & 35 & 16 & 1026 \\
July & 1114 & 54 & 29 & 16 & 1213 \\
August & 973 & 58 & 33 & 13 & 1077 \\
September & 792 & 66 & 48 & 12 & 918 \\
October & 837 & 62 & 53 & 15 & 967 \\
November & 915 & 68 & 63 & 17 & 1063 \\
December & 1145 & 69 & 58 & 20 & 1292 \\
\hline Average & 1200 & 50 & 46 & 16 & 1312 \\
\hline
\end{tabular}

Table 4. Raw materials supplied to the biogas plant by percentage, ratio and price per $\mathrm{kg}$ at Chandkarim community

\begin{tabular}{lccccc}
\hline \multirow{2}{*}{ I tem } & \multicolumn{4}{c}{ Category of raw materials } \\
\cline { 2 - 6 } & Cowdung & $\begin{array}{c}\text { Poultry } \\
\text { droppings }\end{array}$ & $\begin{array}{c}\text { Kitchen } \\
\text { waste }\end{array}$ & Other & Comment \\
\hline Feeding to biogas plant (\%) & 91 & 5 & 3 & 1 & Depends on availability \\
\hline $\begin{array}{l}\text { Feeding to biogas plant } \\
\text { (water : material) }\end{array}$ & $1: 1$ & $1: 2$ & $1: 0.5$ & $1: 1$ & Depends on raw materials \\
\hline Average price Tk. per $(\mathrm{kg})$ & 0.50 & 0.55 & 0.90 & 0.50 & Including carrying cost \\
\hline
\end{tabular}

Table 5. Yearly income and expenditure of chandkarim community biogas plant

\begin{tabular}{clccc}
\hline Serial & Major items & Expenditure (Tk.) & Gross Income (Tk.) & Gross margin (Tk.) \\
\hline 1 & Organic fertilizer & 340674 & 478220 & 137546 \\
2 & Biogas supply & 39000 & 93600 & 54600 \\
3 & Biogas Generator & 41000 & 75600 & 34600 \\
4 & Deep tube well & 42000 & 68400 & 26400 \\
\hline & Total & 762674 & 1032820 & 270146 \\
\hline
\end{tabular}


Sarkar and Uddin (2013) Bang. J. Anim. Sci. 42 (2): 165- 173

Table 6. Source wise yearly income $\&$ expenditure of chandkarim community biogas plant system

\begin{tabular}{|c|c|c|c|c|c|c|c|c|}
\hline \multirow[t]{2}{*}{ Item } & \multicolumn{4}{|c|}{ Yearly expenditure (Tk.) } & \multicolumn{4}{|c|}{ Yearly income (Tk.) } \\
\hline & Input & Labor & Other & Total & House-hold & Farm & Total & Net income \\
\hline Deep tube well & 24000 & $\begin{array}{c}12000 \\
(1)\end{array}$ & 6000 & 42000 & $20400(17)$ & $\begin{array}{c}48000 \\
(2)\end{array}$ & 68400 & 26400 \\
\hline Biogas generator & 12000 & $\begin{array}{c}24000 \\
(1)\end{array}$ & 5000 & 41000 & $51600(43)$ & $\begin{array}{c}24000 \\
(2)\end{array}$ & 75600 & 34600 \\
\hline Biogas supply & 12000 & $\begin{array}{c}24000 \\
(1)\end{array}$ & 3000 & 39000 & 81600 ( 17) & $\begin{array}{c}12000 \\
(1)\end{array}$ & 93600 & 54600 \\
\hline $\begin{array}{l}\text { Organic fertilizer } \\
\text { (Waste@0.52/kg× } \\
478220 \mathrm{~kg} \text { ) }\end{array}$ & 248674 & $\begin{array}{c}87000 \\
(76)\end{array}$ & 5000 & 340674 & - & - & 478220 & 137546 \\
\hline
\end{tabular}

Figures in the parenthesis indicate number of users

\section{Seasonal variation}

As part of qualitative investigations, seasonality mapping was done in the study village. Substantial seasonal variations have been found in terms of availability of raw materials, biogas availability and quantity of bio-fertilizer produced. Figure 1 indicates the seasonality analysis for the community based biogas plant.

According to respondents opinion the month of April is the best time for the availability of cowdung because of confinement of cattle in their shed. The cows produce more dung during the three months of rainy season (Figure 1). As a result biogas production increases as well. Moreover, the higher moisture content in the dung also helps generating more gas. Hence, availability of cowdung is more; bio-fertilizer also produced in more quantity during rainy season. However, the scenario get reverse for the cowdung based plants in winter. Availability of cowdung reduces significantly and due to that biogas and slurry production quantity declined as shown in Figure 2 and 3.

It is to be noted here that the fact is that traditional pit system of producing compost is less available as it is difficult to store and often gets washed away by rain almost $50-60 \%$. The winter is bad for availability of both raw materials and biogas as well. However, the rainy season is not particularly good for management of bioslurry. The rain washes away the bio-slurry and the quality of it is affected by rain-water. Thus, although the rainy season is good for performance of the plants in terms of gas production but the slurry management is more complicated. In 2012 community managed $4,78,220 \mathrm{~kg}$ degradable waste and produced about $17,216 \mathrm{~m}^{3}$ of biogas and utilized that gas for cooking and electricity generation which on monthly charged basis community could able to supply 17 households (Tk. 400/m) and one dairy farm (Tk. 2000/m) for cooking purposes and connected 43 households (Tk. 100/m) with electricity (Table 6).

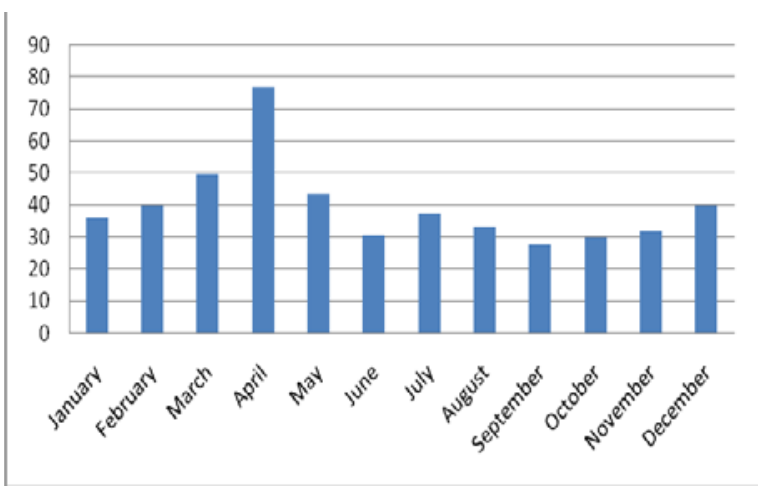

Figure 1. Waste availability in chandkarim community

\section{Hygienic conditions}

Managing of animal and other degradable wastes in biogas systems obviously improves hygienic conditions for the plant owners, their families and the entire village community. Biogas system eliminates the need for household's level waste dumping pits, thereby substantially improving the hygienic conditions in the village concerned. In addition, noxious odors are avoided, because the decomposed slurry stored in such pits is odorless. 


\section{Community waste management}

\section{Reduction of disease transmission}

Since biogas slurry does not attract flies or other vermin, the vectors for contagious diseases for humans and animals alike, are reduced. Furthermore, respiratory problems attributable to soot and smoke from the burning of dried cow dung and firewood are mitigated.

Particularly in the rural areas of Bangladesh as long as inadequate sanitary and hygienic conditions prevail, the health of the rural people will remain threatened. The anaerobic digestion of animal and other organic wastes and effluents extensively detoxifies such material by killing most of the ova and pathogenic bacteria. It is not surprising that the widespread popularization of biogas in Bangladesh has had immediate beneficial effects on the sanitary conditions of the areas concerned. As soon as the introduction of biogas technology fully covered an area, no more animal or organic wastes were deposited in the open pits. This would help eliminate some of the main sources of infectious diseases e.g. tapeworm, schist-soma etc.

\section{Economic aspect of disease reduction}

With regard to the smoke reduction in the kitchen for the user of biogas technology, health effects are tangible. The reduction of diseases can only be felt if the number of biogas systems in an area reaches a critical threshold. Similarly, for a larger entity like village, district or nation, health impacts of biogas systems do not grow as a linear function of the numbers of biogas units installed. Analyses with caution - be done to estimate the value of health benefits in a comparable region that is targeted for a biogas program.

\section{Social acceptance and tradition}

The women and children of poor families in rural areas traditionally expected that they collect fuel wood and cowdung, now have more free time and are more likely to attend school. Finding also shows that the use of biogas systems gives women more time to engage to the family affairs as well as caring of their children to boost up nations' development. The use of biogas for lighting can lead to remarkable changes in the way families integrate in the cultural and educational sectors. Biogas lighting makes it possible to engage in activities at night such as reading or attending evening schools.

\section{Employment Generation}

During construction period of biogas plant, an opportunity of short-term employment is generated and income is generated due to the need for excavation, metal-work, masonry and plumbing. Again, the subsequent operation and maintenance of the biogas systems can have long-term beneficial effects on regional employment and income. Community plants require a permanent/seasonal staff for plant management, raw material procurement, plant operation and maintenance, distribution of electricity, water and biogas and for disposal, processing and packaging of organic fertilizer for the marketing.

\section{Conclusion}

Community based approach for managing waste is playing an important role for mitigating daily energy needs of rural households at Chandkarim village. Community based biogas plants may be considered as an efficient technology for managing all sorts of degradable waste to reduce diseases both for human and animal as a means of economic and sustainable environment.

In chandkarim community, neither grid nor piped supply gas is available for those areas. To make available required energy decentralized supply systems like biogas; solar, wind, etc. may be considered as better alternatives. To face this indispensable situation, finding alternative of renewable sources of energy is the only option. This area has a wonderful climate for biogas production. Community approach of managing and utilization of waste through biogas technology proved to be suitable and affordable one of those. They touched the success of producing biogas as a means of renewable energy source for cooking and electricity generation, bio-fertilizer, sustainable livelihoods and friendly environment through community led waste management approach instead of traditional family based biogas plant.

These technology need to be standardized and popularized for dissemination in rural 
Bangladesh. However, community may need motivational support for owning this technology to maintain all sorts of degradable waste especially for livestock and to have a sustainable environment. The Government along with NGOs and private sector institutions should initiate programs for extension and dissemination of this technology as a strategy of replicating this model by installing community led, "One Village One Biogas Plant". For national or regional planning, however, the reduction of deforestation and consequent soil erosion is one of the main arguments to allocate government funds for the dissemination of biogas technology. While a ready-made formula cannot be offered to calculate the monetary value of biogas in terms of reducing deforestation, some guiding questions may assist the planner to realistically assess the profitability of community based biogas approach compared to other conventional systems.

\section{References}

Chowdhury SA, Tareque AMM, Akbar MA (1987). Manure yield by cattle and buffalo of Bangladesh. Bangladesh Journal of Agricultural Science. 14: 21-29.

Dasgupta S, Mainul H, Khaliquzzaman M, Kiran P, David W (2004). Who suffers from indoor air pollution? Evidence from Bangladesh. The World Bank, Development Research Group, Policy Research Working Paper 3428.

Delgado C, Rosegrant M, Steinfeld H, Ehui S, Courbois C (1999). Livestock to 2020 - The next food revolution, Food, Agriculture, and the Environment Discussion Paper 28, P. 72. IFPRI, FAO, ILRI, Washington, USA.

DLS (2000) Department of Livestock Services; An overview.

Gofran MA ( 2007). Status of biogas technology in Bangladesh. The Daily Star: Wednesday, September 5, 2007.

Hossain MMG ( 2011). I mproved cookstove and biogas programmes in Bangladesh. Energy for International Energy Agency (IEA). IEA Guide to Reporting Energy RD and $D$ Budget/Expenditure Statistics, Paris Cedex 15, France.
Islam MH, AKMM Rahman, MA Hashem, MSI Hossain (1999). Women's participation in dairying. Bangladesh Journal of Animal Science, 28: 21-27.

Mamun MRA, Kabir MS, Alam MM, Islam MM (2009). Utilization pattern of biomass for rural energy supply in Bangladesh. International Journal of Sustainable Crop Production, 4: 62-71.

Ministry of Planning (2011). Population and Housing Census. Bangladesh Bureau of Statistics (BBS), Planning Division, Government of the People's Republic of Bangladesh.

Paul DC, Saadullah M (1991). Role of women in homestead of small farm category in an area of Jessore, Bangladesh. Livestock Research for Rural Development, 2: 23-29.

Rabbani MA, Satter MA, Inoue E, Sarker RI, (2011). A case study on the availability of crop biomass in the rural area. Proceedings of the International Conference on Environmental Aspects of Bangladesh.

Shahjalal M, Biswas MAA, Tareque AMM (1997). Effect of feeding Sesbania leaves on growth and nutrient utilization in goats. Bangladesh Journal of Animal Science, 26: 117-123.

Steinfeld H, Chilonda P (2006). Old players, new players, Livestock Report 2006, 3-14, Animal Production and Health Division, FAO, Rome. Sustainable Development, 7: 97-100.

Uddin MS (1991). The effect of different dietary protein and energy levels on the performance of layer strain chicken in Bangladesh. PhD.Thesis, Department of Animal Nutrition, BAU, Mymensingh.

Wim J, Willem B, Khurseed-UI-Islam (2005). Feasibility of a national programme on domestic biogas in Bangladesh, Final report. Netherlands Development Organization Biogas Practice Team, 161: 12-13.

World Bank (2012). Development Research Group, Policy Research Working Paper 3428. 